\title{
MODEL PEMBELAJARAN YANG MENYENANGKAN BERBASIS PEMINATAN
}

\author{
Diana Wulandari \\ Mahasiswa Master Psikologi Pendidikan Universiti Utara Malaysia \\ E-mail : wulandaridiana87@gmail.com
}

\begin{abstract}
Abstrak
Tujuan dari penelitian ini adalah bagaimana penerapan konsep-konsep pembelajaran untuk menciptakan model pembelajaran yang menyenangkan. Metode yang digunakan dalam penelitian ini adalah kualitatif-deskriftif, pendekatan ini menitikberatkan pada pemahaman, pemikiran, dan persepsi peneliti. Hasil dari persepsi peneliti terhadap berbagai materi mengenai model pembelajaran yang menyenangkan berbasis peminatan, bahwa seorang siswa memiliki minat yang berbeda pada materi pelajaran tertentu di sekolah. Hal itu tidak bisa dilepaskan dari model pembelajaran yang menyenangkan, sehingga siswa tersebut memiliki minat untuk terus mempelajari materi tersebut pada jenjang pendidikan selanjutnya.
\end{abstract}

Kata kunci : Model Pembelajaran, Minat, Bakat

\begin{abstract}
The purpose of the preparation of this paper is how the application of these concepts to create a model of learning fun learning. The method used in the preparation of this paper is qualitativedescriptive, this approach focuses on understanding, thinking, and perception researchers. The results of the perception of authors of various materials on a fun-based learning model of specialization, that a student has a different interest in a particular subject matter in school. It can not be separated from the model of learning fun, so that young people have an interest to continue studying the material in further education.
\end{abstract}

Keywords : Learning Model, Interest, Talent

\section{PENDAHULUAN}

Pembukaan Undang-Undang Dasar 1945 mengamanatkan bahwa pembentukan Pemerintah Negara Indonesia yaitu antara lain untuk mencerdaskan kehidupan bangsa. Untuk mewujudkan upaya tersebut, UndangUndang Dasar 1945 Pasal 31 Ayat (3) memerintahkan agar Pemerintah mengusahakan dan menyelenggarakan satu sistem pendidikan nasional, yang meningkatkan keimanan dan ketakwaan serta akhlak mulia dalam rangka mencerdaskan kehidupan bangsa, yang diatur dengan undang-undang.

Perwujudan dari amanat UndangUndang Dasar 1945 yaitu dengan diberlakukannya Undang-Undang Nomor 20 Tahun 2003 tentang Sistem Pendidikan Nasional, yang merupakan produk undang-undang pendidikan pertama di Indonesia pada awal abad ke-21. Undang-undang ini menjadi dasar hukum untuk membangun pendidikan nasional dengan menerapkan prinsip demokrasi, desentralisasi, dan otonomi pendidikan yang menjunjung tinggi hak asasi manusia. Sejak Proklamasi Kemerdekaan 17 Agustus 1945, undangundang tentang sistem pendidikan nasional telah mengalami beberapa kali perubahan.

Pendidikan nasional, sebagai salah satu sektor pembangunan nasional dalam upaya mencerdaskan kehidupan bangsa, mempunyai visi terwujudnya sistem pendidikan sebagai pranata sosial yang kuat dan berwibawa untuk memberdayakan semua warga negara Indonesia berkembang menjadi manusia yang berkualitas sehingga mampu dan proaktif menjawab tantangan zaman yang selalu 
berubah. Makna manusia yang berkualitas, menurut Undang-Undang Nomor 20 Tahun 2003 tentang Sistem Pendidikan Nasional, yaitu manusia terdidik yang beriman dan bertakwa kepada Tuhan Yang Maha Esa, berakhlak mulia, sehat, berilmu, cakap, kreatif, mandiri, dan menjadi warga negara yang demokratis dan bertanggung jawab. Oleh karena itu, pendidikan nasional harus berfungsi secara optimal sebagai wahana utama dalam pembangunan bangsa dan karakter.

Penyelenggaraan pendidikan sebagaimana yang diamanatkan dalam UndangUndang Nomor 20 Tahun 2003 tentang Sistem Pendidikan Nasional diharapkan dapat mewujudkan proses berkembangnya kualitas pribadi peserta didik sebagai generasi penerus bangsa di masa depan, yang diyakini akan menjadi faktor determinan bagi tumbuh kembangnya bangsa dan negara Indonesia.

Salah satu unsur sumber daya pendidikan adalah kurikulum. Kurikulum merupakan unsur yang bisa memberikan kontribusi yang signifikan untuk mewujudkan proses berkembangnya kualitas potensi peserta didik. Kurikulum yang dikembangkan dengan berbasis pada kompetensi sangat diperlukan sebagai instrumen untuk mengarahkan peserta didik menjadi: (1) manusia berkualitas yang mampu dan proaktif menjawab tantangan zaman yang selalu berubah; dan (2) manusia terdidik yang beriman dan bertakwa kepada Tuhan Yang Maha Esa, berakhlak mulia, sehat, berilmu, cakap, kreatif, mandiri; dan (3) warga negara yang demokratis dan bertanggung jawab. Pengembangan dan pelaksanaan kurikulum berbasis kompetensi merupakan salah satu strategi pembangunan pendidikan nasional sebagaimana yang diamanatkan dalam UndangUndang Nomor 20 Tahun 2003 tentang Sistem Pendidikan Nasional.
Untuk mewujudkan harapan tersebut pemerintah melalui Kementrian Pendidikan dan Kebudayaan menerapkan kurikulum 2013. Kurikulum 2013 lebih menekankan praktik daripada hafalan. Dengan Kurikulum 2013, pemerintah ingin menghasilkan bangsa Indonesia yang produktif, kreatif, dan afektif. Dalam kurikulum tersebut anak dibentuk agar memiliki pengetahuan, keterampilan, dan sikap. Dasar pemerintah dalam mengembangkan kurikulum 2013 ini tidak bisa dilepaskan dari 4 landasan, yaitu : (1) Landasan Yuridis. (2) Landasan Filosofis. (3) Landasan Teoritis. dan (4) Landasan Empiris.

Konsekuensi logis dari implementasi kurikulum 2013 ini, mengharuskan pemerintah mempersiapkan berbagai strategi agar kurikulum ini dapat diterapkan dengan baik dan dapat mencapai tujuan yang diharapkan. Pemerintah bertanggungjawab untuk mempersiapkan guru yang kompeten, memberikan evaluasi dan supervisi, serta memberikan bantuan profesional kepada para pendidik dan kependidikan.

Guru sebagai salah satu unsur keberhasilan dari implementasi kurikulum 2013 ini harus mempersiapkan diri, mengembangkan dan meningkatkan kompetensinya, memahami berbagai konsep dan model pembelajaran agar dapat melaksanakan tugasnya sebagai pendidik dengan baik. Salah satu model pembelajaran yang diterapkan adalah model pembelajaran yang menyenangkan, pembelajaran yang kreatif dan menarik, agar dapat menumbuhkan minat, bakat, dan kemampuan siswa dalam memahami materi pelajaran yang diajarkan.

\section{BAHASAN UTAMA}

Filosofi inti Kurikulum 2013 menuntut siswa untuk menjadi aktor utama dalam proses pembelajaran. Sebagaimana landasan filosofis Pendidikan nasional yang berfungsi mengembangkan dan membentuk watak serta peradaban bangsa yang 
bermartabat dalam rangka mencerdaskan kehidupan bangsa. Untuk mengembangkan dan membentuk watak dan peradaban bangsa yang bermartabat, pendidikan berfungsi mengembangkan segenap potensi peserta didik menjadi manusia yang beriman dan bertaqwa kepada Tuhan Yang Maha Esa, berakhlak mulia, sehat, berilmu, cakap, kreatif, mandiri, dan menjadi warganegara yang demokratis serta bertanggungjawab. Guru hanya melempar topik belajar kepada siswa dan membiarkan mereka mengeksplorasi sendiri. Guru menjadi fasilitator yang hanya memantau proses belajar siswa, membantu dalam menanggapi pertanyaan, dan menyediakan sumber daya yang diperlukan siswa. Oleh karenanya seorang guru harus memiliki berbagai pendekatan dan model, dan strategi dalam pembelajaran yang menyenangkan, sehingga siswa mampu menunjukkan minat, bakat, kemampuan yang dimilikinya.

\section{Strategi Pembelajaran Menyenangkan}

Pengertian strategi pembelajaran yang menyenangkan dikemukakan oleh beberapa ahli di antaranya adalah Darmansyah (2010) dalam DePorter (2000) menyatakan bahwa strategi pembelajaran yang menyenangkan adalah strategi yang digunakan untuk menciptakan lingkungan belajar yang efektif, menerapkan kurikulum, menyampaikan materi dan memudahkan proses belajar. Sementara Berk (1998) adalah pola berbikir dan arah berbuat yang diambil guru dalam memilih dan menerapkan cara-cara penyampaian materi sehingga mudah dipahami siswa dan memungkinkan tercapainya suasana pembelajaran yang tidak membosankan bagi siswa. Sedangkan Deporter, Reardon dan Singer (1999) adalah kemampuan untuk mengubah komunitas belajar menjadi tempat yang meningkatkan kesadaran, daya dengar, pertisipasi, umpan balik dimana emosi dihargai.
Guru yang professional adalah mengerti cara memberikan pelajaran baik. Mereka dapat menyampaikan materi secara maksimal kepada siswa sehingga tujuan pembelajaran dapat tercapai dengan maksimal. Untuk dapat mencapai tujuan tersebut memang bukan hal yang mudah. Oleh karena itulah, guru perlu memiliki sifat sabar dan mempelajari model-model pembelajaran. Guru perlu sabar karena ini akan memengaruhi perkembangan siswa itu sendiri. Jika guru sering memperlihatkan kekerasan, maka siswa akan berkarakter sama dengan si pendidik. Akan tetapi, kalau kita mengajarkan sesuatu dengan cara yang baik, maka karakter mereka juga akan baik pula. Hal ini juga berlaku dalam proses pembelajaran pada anak sekolah dasar di dalam kelas. Saat seorang guru memperlihatkan wajah seram di kelas, maka suasana belajar jadi menyeramkan. Berbeda dengan ketika guru tersebut selalu terlihat ramah dan tersenyum kepada siswasiswanya. Guru perlu menciptakan suasana yang menyenangkan agar siswa tidak merasa terbebani. Akan lebih bagus lagi jika guru juga menyampaikan materi dengan metode pembelajaran yang interaktif (Rofalina, 2013).

\section{Pembelajaran Berbasis Peminatan}

Setiap siswa memiliki minat, bakat, dan kemampuan yang berbeda. Perbedaan tersebut merupakan sunnatullah dan tidak perlu dipertentangkan. Keberagaman tersebut merupakan suatu kekayaan yang tidak ternilai. Untuk mengembangkan kekayaan berupa minat, bakat, dan kemampuan yang ada pada disri setiap siswa tersebut dibutuhkan suatu konsep, modal, dan strategi dalam pembelajaran.

Pelaksana pendidikan diperlukan memiliki pemahaman yang komprehensip tentang hakikat minat (interest), bakat (talent), dan kemampuan (capability). Ketiganya memiliki hubungan yang sangat 
terkait satu sama lain, walaupun sebenarnya ketiganya memiliki makna masing-masing yang berbeda. Dari website Psychology Mania, tertulis bahwa minat (interest) adalah (1) satu sikap yang berlangsung terus menerus yang menjadi pola perhatian seseorang sehingga membuat dirinya jadi selektif terhadap objek minatnya, (2) perasaan yang menyatakan bahwa satu aktivitas, pekerjaan, atau objek itu berharga atau berarti bagi individu, (3) satu keadaan motivasi, atau satu set motivasi, yang menuntun tingkah laku menuju satu arah (sasaran) tertentu. Sementara itu, bakat (talent) adalah kemampuan yang dimiliki seseorang sejak lahir. Kemampuan itu sendiri, adalah the ability to perform actions. Atau dalam kata lain, capability is the sum of capacity and ability (Premono, 2013)

Seseorang bisa jadi memiliki minat terhadap sesuatu namun belum tentu sesuai dengan bakat dan kemampuannya. Biasanya, seseorang akan sangat berminat terhadap suatu bidang tertentu (pelajaran) karena memang mereka mengerti betul akan kemampuan dan bakatnya terhadap bidang tersebut. Untuk itulah, Satu sisi yang harus diikutkan dalam pembicaraan sebuah minat adalah bakat dan kemampuan. Jika seseorang memiliki sebuah minat terhadap satu bidang tertentu, sudah seharusnya untuk diberikan kesempatan mempelajarinya. Tetapi jika kita berbicara sebuah sistem dan sistem tersebut memiliki banyak pendukung di dalamnya, sesungguhnya semuanya harus dikembalikan kepada seluruh pendukung sistem tersebut agar semua bisa berjalan seperti yang diinginkan.

\section{Pembelajaran Yang Menyenangkan Berbasis Peminatan}

Minat siswa terhadap suatu pelajaran sekolah tidak bergantung pada materi pembelajaran, tetapi bergantung pada cara guru mengajar. Materi pelajaran yang sulit bisa menjadi menyenangkan apabila disampaikan oleh guru yang menyenangkan. Sebaliknya, materi pelajaran yang sebenarnya mudah bisa menjadi membosankan apabila disampaikan oleh guru yang tidak menyenangkan. Oleh karena itu, seorang guru harus memiliki metode-metode dan strategi khusus yang dapat membuat para siswa senang mengikuti kelasnya (Grafura \& Wijayanti, 2012).

Hakekat peminatan dalam pembelajaran kurikulum 2013 adalah fasilitasi bagi perkembangan peserta didik agar peserta didik secara aktif mengembangkan potensi dirinya sehingga mencapai perkembangan optimum. Proses pengambilan pilihan dan keputusan oleh peserta didik dalam bidang keahlian yang didasarkan atas pemahaman potensi diri dan peluang yang ada. Bimbingan dan konseling membantu peserta didik untuk memahami diri, menerima diri, mengarahkan diri, mengambil keputusan diri, merealisasikan keputusannya secara bertanggung jawab. Model pembelajaran diharapkan dapat membantu mengembangkan potensi peserta didik sesuai dengan minat, bakat, dan kemampuan yang dimilikinya.

Beberapa model pembelajaran yang menyenangkan bisa dilakukan dengan permainan (game). Permainan ini dikaitkan dengan materi pelajaran yang diajarkan sehingga siswa tidak bosan, dan secara periodik dievaluasi, sehingga diketahui minat masing-masing siswa dalam memahami materi pelajaran yang diajarkan.

Selain itu model pembelajaran dengan humor (Dananjaya, 1999) sebagaimana yang dikutip oleh Darmansyah (2010) mengatakan humor adalah sesuatu yang bersifat dapat menimbulkan atau menyebabkan pendengarannya merasa tergelitik perasaan lucunya, sehingga terdorong untuk tertawa. Pengaruh humor di ruang kelas diantaranya: (1) Humor membangun hubungan dan meningkatkan 
komunikasi. (2) Humor sebagai alat pengurang stress. (3) Humor membuat pelajaran menjadi menarik. (4) Humor memperkuat daya ingat.

Humor juga memiliki manfaat dalam pendidikan, diantaranya adalah : (1) Humor sebagai pemikat perhatian siswa. (2) Humor mengurangi kebosanan dalam belajar. (3) Humor membantu mencairkan ketegangan di dalam kelas. (4) Humor membantu mengatasi kelelahan fisik dan mental dalam belajar. (5) Humor memudahkan komunikasi dan interaksi (Darmansyah, 2010). Manfaat humor dalam pendidikan tidak bias dilepaskan dari kaitan kecerdasan emosional, otak dan humor itu sendiri. Kaitan kecerdasan emosional,otak dan humor dalam proses pembelajaran adalah : otak (neocortex) bereaksi setelah melalui proses internalisasi pada otak emosi (mamalia). Jika otak emosi dapat berfungsi dengan baik maka otak berpikir akan mampu melaksanakan tugasnya dalam memproses informasi. Pemrosesan informasi akan efektif apabila suasana menyenangkan. Salah asatu cara untuk pembelajaran menyenangkan adalah dengan menciptakan humor saat berinteraksi dengan siswa. Potensi humor dalam menciptakan pembelajaran yang menyenangkan perlu didukung oleh kecerdasan emosional yang memadai. Karena kecerdasan emosional ikut menentukan keberhasilan proses dan hasil belajar (Syah, 1996).

\section{KESIMPULAN DAN SARAN}

\section{Kesimpulan}

Dari pembahasan atas kajian yang didasarkan pada fenomena penerapan kurikulum 2013, dapat disimpulkan sebagai berikut :

1. Kurikulum 2013 memiliki landasan yuridis, filosofis, teoritis, dan empiris, yang tujuannya untuk mengusahakan dan menyelenggarakan satu sistem pendidikan nasional, yang meningkatkan keimanan dan ketakwaan serta akhlak mulia dalam rangka mencerdaskan kehidupan bangsa, yang diatur dengan undang-undang.

2. Harapan tersebut dapat dicapai jika semua unsur yang terlibat dalam pendidikan, yaitu pemerintah, masyarakat, lembaga pendidikan, dan guru memahami tugas dan fungsinya masingmasing.

3. Guru memiliki tugas yang tidak ringan, yaitu harus meningkatkan dan mengembangkan kompetensinya, serta memiliki pemahaman yang komprehensif terhadap konsep, model, dan strategi pembelajaran yang menyenangkan.

4. Model pembelajaran yang menyenangkan berbasis peminatan berusaha memotret minat, bakat, dan kemampuan siswa, sehingga siswa memiliki kemampuan untuk mengembangkan minat dan bakat yang dimilikinya.

\section{Saran}

Adapun saran yang dapat dihasilkan dari hasil penulisan makalah ini adalah sebagai berikut :

1. Pemerintah secara intensif memberikan dan mengadakan pelatihan kepada guruguru, terkait dengan implementasi kurikulum 2013

2. Lembaga pendidikan baik dasar, menengah, dan tinggi harus memikirkan kembali model pembelajaran yang sesuai dengan kondisi minat, bakat, dan kemampuan yang dimiliki oleh tiap siswa.

3. Lembaga pendidikan baik dasar, menengah, dan tinggi juga harus memikirkan keberadaan guru BK untuk membantu memberikan konseling bagi anak didik dalam mengembangkan minat, bakat, dan kemampuannya. 


\section{Ucapan Terimakasih}

Terima kasih kami sampaikan kepada Bapak Kepala Sekolah SDN Bululawang 1 Kabupaten Malang yang telah mendukung kami untuk aktif di berbagai kegiatan ilmiah, serta sumbangsih pemikirannya, sehingga penelitian ini bisa terselesaikan dengan baik. Kepada seluruh keluarga besar SDN 1 Bululawang Kabupaten Malang, teman-teman guru dan siswa-siswi atas dorongan morilnya.

\section{DAFTAR PUSTAKA}

Berk, Laura E. (1998). Development through the lifespan. Pearson. United Kingdom.

Darmansyah. (2010). Strategi pembelajaran menyenangkan dengan humor. Jakarta: Bumi Aksara.

DePorter, Bobbi; Reardon, Mark; dan Singer-Nourie, Sarah. (1999). Quantum teaching: Mempraktikkan quantum learning di ruang-ruang kelas (terjemahan Ary Nilandari). Bandung: Penerbit Kaifa.

DePorter, Bobbi. (2000). Quantum teaching/learning. Bandung. Kaifa.

Dananjaya, James. (1996). Foklor Indonesia. Jakarta: Pustaka Utama Grafiti

Dikti. (2003). UU RI nomor 20 tahun 2003 tentang Sistem Pendidikan Nasional
Dikti. (2013). Dokumen Kurikulum 2013

Dikti. (2013). Materi Pelatihan Pengelolaan Pembelajaran Berdasarkan Peminatan

Grafura, Lubis; Wijayanti, Ari. (2012). Metode dan strategi pembelajaran yang unik. Yogyakarta: Ar-Ruzz Media.

Harahap, Rahmad Faisal. (2013). Kurikulum 2013 Sangat Mendadak dan Tergesagesa.

http://kampus.okezone.com/read/2013/ $\underline{12 / 27 / 560 / 918322 / \text { kurikulum-2013- }}$ sangat-mendadak-tergesa-gesa.

Diakses, 10 Juli 2016.

http://www.republika.co.id/berita/pendidika n/eduaction/13/12/11/mxn1xqkurikulum-2013-menekankan-praktikbukan-hafalan. Diakses, 10 Juli 2016.

Premono, Agung. (2013). Minat, Bakat, dan Kemampuan: Tinjauan Kurikulum 2013.

http://majalah1000guru.net/2013/04/ minat-bakat-kemampuan/. Diakses, 10 Juli 2016.

Rofalina, Fanny. (2013). Kurikulum Membingungkan, Pendidikan Terancam. http://news.liputan6.com/read/784373/ kurikulum-membingungkanpendidikan-terancam. Diakses, $10 \mathrm{Juli}$ 2016.

Syah, M. (1996). Psikologi pendidikan suatu pendekatan baru. Bandung: PT Remaja Rosdakarya,. 